
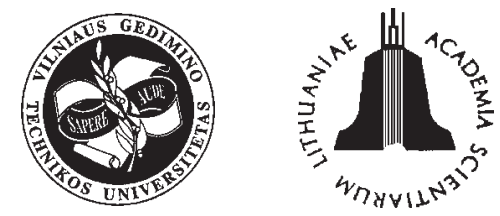

ISSN 1392-3730 print / ISSN 1822-3605 online

JOURNAL OF CIVIL ENGINEERING AND MANAGEMENT

http:/www.jcem.vgtu.lt

2006, Vol XII, No 1, 37-42

Enorgy Process Treogration in Ruildings.

\title{
AN ESTIMATION OF EXERGY CONSUMPTION PATERNS OF ENERGY-INTENSIVE BUILDING SERVICE SYSTEMS
}

\author{
Darius Biekša, Vytautas Martinaitis, Aloyzas Algimantas Šakmanas \\ Dept of Heating and Ventilation, Vilnius Gediminas Technical University, \\ Sauletekio al.11,LT-10223 Vilnius-40,Lithuania.E-mail: dariusb@ap.vtu.lt
}

Received 25 May 2005; accepted 05 Dec 2005

\begin{abstract}
This paper represents the estimation of life cycle exergy consumption for building service systems (BSS). The investigation explores public building engineering systems, which are the most energy-intensive. These include heating, ventilating and lightning. The exergy consumption analysis is divided into three parts: systems production, operating and maintenance (O\&M) and decommissioning. The differences between them consist in different exergy demand and consumption intensiveness. The main attention is paid to BSS O\&M investigation by categorising and defining exergy demands within the building. Exergy consumption for BSS O\&M period is estimated as certain amount of exergy that should be supplied to the buildings boundaries. In this investigation of building engineering systems, 4 typical buildings are explored for the Vilnius' city conditions in Lithuania.
\end{abstract}

Keywords: building engineering systems, exergy consumption, process integration.

\section{Introduction}

This paper investigates buildings service systems energy consumption patterns. The problem analysed could be described as an internal thermo-dynamical task to estimate requirements for building's energy quality and quantity in order to meet indoor environment conditions.

\section{Methods}

Buildings are an energy-intensive technical system. Due to the energy demand, a building's technical system can be divided into two parts: construction and buildings service systems. The construction consists mainly of walls, spans etc. The greatest part of energy is consumed in the manufacture of materials and directly in the process of construction. Having in mind that the analysis will be carried out and will cover all the building's lifetime, the construction part must also involve the energy demand that is needed for repairs, renovations and finally for the decommissioning of a building [1].

To the engineering part belong the service systems that ensure comfortable conditions of the indoor environment. These include heating, ventilation, cooling, lighting, communication, security and other systems, which consume energy, materials or information in their own way.

In order to define exergy consumption during a building's lifetime, it is necessary to invoice the typical periods of the systems. Secondly, the exergy demand for these periods should be calculated too.

The system's lifetime can be divided into three periods:

1. System's production,

2. System's operating and maintenance $(\mathrm{O} \& \mathrm{M})$,

3. System's decommissioning.

Each of these life periods can be analysed in a more detailed way.

System's production involves steps such as production and the installation of the system.

The "4 level of cumulative energy model" was applied to complete the exergy demand analysis for a system's production period [2].

The exergy amount required to create one unit of final production can be calculated according to the algorithm presented in $[3,4]$. By this methodology, all the exergy losses that emerge during the processes are summarised.

Exergy consumption for one production unit can be calculated as:

$$
\begin{gathered}
E_{P U}=M_{C} \cdot e_{C}+\sum_{i=1}^{n} \frac{L_{a, i}+L_{t, i}}{M_{p, i}}= \\
M_{C} \cdot e_{C}+\sum_{i=1}^{n} \frac{E_{i}+E_{p, i-1}-E_{p, i}}{M_{p, i}}
\end{gathered}
$$


where $M_{C} \cdot e_{C}$ - amount of fuel chemical exergy in the raw material; $L_{t, i}, L_{a, i}$ - exergy losses with pollution emissions and waste during process $i ; M_{p, i}$ - mass flow produced during process $i ; E_{i}$ - exergy flow supplied to the system during the process $i ; E_{p, i-1}$ - exergy flow supplied to the system during process $i$ from the previous process $i-1 ; E_{p, i}-$ during process $i$ produced exergy flow, which passes to the next process. Summarising all the exergy expenditures for all the process, we may conclude with the total exergy amount needed to create one production item.

During the O\&M period the BSS were actively employed. The activities also included performing preventive and corrective maintenance (ie fixing breakdowns etc). The exergy consumption, as distinct from the system production period, is evaluated as the consumed amount of exergy at the buildings boundary.

In order to have a consistent view on the building's exergy demand, some concepts should be firstly discussed. Unavoidable exergy flow is a fixed exergy flow (in relation to the known or assumed environment conditions) that is necessary to compensate exergy losses due to the heat transfer through building envelope and performing ventilation air parameters regulation. The estimation of unavoidable exergy flow quantitative parameters is based on attitude that buildings environment should meet certain sufficient level of indoor comfort as external environment conditions are defined by variation of outdoor temperature. In an ideal way, unavoidable exergy flow could be defined as minimal building exergy requirements. Having in mind some reservation, electrical power demand for lighting can be also referred to as unavoidable exergy flow. In this case it is necessary to point out that light generation using electrical power is convenient and therefore widespread but, from the thermo-dynamical point of view, not the only (or optimal) one. Looking purely theoretically, during a simple fuel combustion process (naturally, using particular technologies) the set of different energy output can be generated: light, heat, cold and electricity (additionally, different gas concentration potential created in space due to flue gas emission can be evaluated). As it has been mentioned before, the electricity demand for building indoor environment, particularly for lighting, is connected with the widespread and global technology and that's why electrical energy type for building lighting systems only with some reservation can be added to the unavoidable exergy flow.

The mentioned above unavoidable exergy flows describe buildings minimal exergy requirements in an ideal case, they are not related to the technology applied in BSS. An illustrating hypothetic example can be presented: if we could have a perfect fuel transformer able to transmit all the fuel chemical energy into the unavoidable exergy flow (without losses), in this cases this exergy flow will become buildings minimal exergy flow. Taking into consideration the present technological level, real processes always inflict exergy losses. For that reason, next to the unavoidable exergy flow it is necessary to introduce additional components of building minimal exergy flow - technological exergy flow.

Having in mind the principle and structure of real $\mathrm{BSS}$, the overall exergy flow could be divided into two components:

- The unavoidable flow; it has no relation to the technology used and is determined only by building indoor and outdoor environment conditions.

- Technological exergy flows, in their turn, can be divided into:

1) processes flow; it depends on energy transport and dispersion methods, in this way on technology;

2) device flow; it has a direct link with equipment and supplied energy efficient use;

3) mono systems; they generate additional exergy demands due to the particular construction and operation mode of the system (mono systems can be defined as BSS that has a single energy carrier/work agent: heating (hot water), ventilation (air) etc).

As it was presented, technological exergy flow can be divided into 3 groups. Tangible exergy flow losses appear when different thermodynamical processes take place. For example, exergy flow transformation during heat transfer (heat exchange), that provoke energy potential drop (devaluation), flow phenomenon etc.

Another reason for permanent exergy flow is technical perfection of devices used in mono (poly) systems. In the first place it relates to the equipment efficiency problem.

Specific connection of processes and devices in a common system determines additional exergy losses due to the system structure and specific operational mode features.

BSS technological exergy flow minimisation is a key priority increasing building energy consumption efficiency. BSS integration has one of the biggest potential in this area. It is important to mark that BSS integration concept should not be narrowed and perceived only as a control of a few mono systems. Certainly there are some features of integration but the true meaning should be understood more broadly. Search for integrated BSS solutions should be based on coherent investigation of processes, devices and systems individual and parallel energy demands. Integration nature consists of critical assessment of existing systems and identifying possible technological solutions for sustainable systems creation. In this case BSS integration could be presented as balanced incorporation of separate mono systems taking in to consideration designing, mounting and maintaining phases.

When summarising, it could be stated that every building has its own, individual unavoidable exergy demands, which can be calculated having information about construction features and required final user's environment comfort level. The other part of BSS exergy demand associates with technological exergy flows. The function of this component is to compensate exergy losses, which appear during transportation of unavoidable exergy flows from building boundaries to the final user's environment (where a required comfort level is to be secured). In actual BSS, exergy flow (heat) transportation is realised through heat 
agent circuits (hot water, steam, air etc). These cycles from receiving exergy flow at the buildings boundaries until submitting it to the heated room contain all the components of technological exergy flow: processes, devices and systems.

This paper pays more attention to the investigation of flow process and device exergy demands.

During a building's O\&M period the energy consumption for hot water (or air) transport could be estimated as $\dot{E}_{p}=\Delta p \cdot \dot{V}$, where $\Delta p$ - pressure losses in the network, $\mathrm{Pa} ; \dot{V}$ - hot water or airflow, $\mathrm{m}^{3} / \mathrm{s}$. This relationship is universal and it allows for an estimation of the energy consumption in different systems. By performing a system comparison, it is easier to operate with universal and comparable indicators. One of these could be the relation between presser (pump or fan) and the required heat demand capacities $\dot{E}_{p} / \dot{Q}_{t h}$. The required heat capacity for heating and ventilation systems could be traced by fluid properties.

In these systems, the fluid transportation pressure losses can be expressed by the network resistance (or system line) characteristics. Assuming that the fluid flow properties in the system do not change significantly, the relation between velocity, flow rate and diameter could be written as $c=4 \cdot \dot{V} /\left(\pi \cdot d^{2}\right)$. Pressure losses in the network are proportional to the rate square $\Delta p=\sigma \cdot \dot{V}^{2}$, where $\sigma-$ network resistance characteristic. They can be calculated according to $\Delta p=\sum(R \cdot l+Z)$, where

$$
R=\frac{\lambda}{d} \cdot \frac{c^{2} \cdot \rho}{2 \cdot g}
$$

$R$ - pressure losses due to the friction in the system, $\mathrm{Pa} / \mathrm{m} ; \lambda-$ coefficient of pressure losses due to friction

$$
Z=\sum \zeta\left(\frac{c^{2} \cdot \rho}{2 g}\right)
$$

$Z$ - pressure losses due to the local obstacles, $\mathrm{Pa}$.

Round diameter network resistance characteristic could be expressed as

$$
\sigma=\left(\frac{l \cdot \lambda}{d}+\sum \zeta\right) \frac{\rho}{2}\left(\frac{4}{\pi \cdot d^{2}}\right)^{2},
$$

$\sum \zeta$ - coefficients sum of pressure losses due to local obstacles in the devices and pipelines.

During calculations it is convenient to estimate the pressure losses due to local obstacles as part of $\varepsilon$ of the total pressure losses. For building heating systems it is recommended to use the ratio 0,65 [5]. The greater influence of devices (filters) on the total system pressure losses is typical for ventilation systems. This is a reason why while performing a detailed analysis, it is necessary to evaluate the type of resistance. For orientation, calculations $\varepsilon$ value could be taken from the interval $0,85-$ 0,98 . Further, the simplified network resistance charac- teristic could be expressed as

$$
\sigma=\frac{l \cdot \lambda}{d \cdot \varepsilon} \frac{\rho}{2}\left(\frac{4}{\pi \cdot d^{2}}\right)^{2} .
$$

The final expression of systems comparable indicator will be $[2,3]$

$$
\frac{\stackrel{\bullet}{E_{p}}}{\dot{Q_{\text {th }}}}=\frac{l \cdot \lambda}{d \cdot 2 \varepsilon} \frac{c^{2}}{c_{p} \cdot\left(t_{\text {in }}-t_{\text {out }}\right)},
$$

where $\boldsymbol{t}_{\text {in }}$ and $\boldsymbol{t}_{\text {out }}$ are corresponding input and output temperature of fluid (hot water or air). Evaluation of pressers and the heat capacities relation enables us to estimate the total building systems energy consumption. Required presser capacity in formula 5 identifies exergy flow that is transmitted directly to the fluid stream ensuring its transportation through hot water or ventilation circuits. This exergy capacity could be applied only under ideal conditions, when the presser itself would not cause any energy losses. But in reality they are always present, they emerge in generator, among moving mechanisms due to the friction and finally during fluid stream tribulation. By establishing energy requirements for pressers it is important to pay a proper attention to overall presser efficiency, duty zone and operation mode. Further some indications will be presented about the existing pressers - in our case pumps - efficiency parameters. Pump overall efficiency varies strongly by the capacity. Falhen [6] in his research has pointed out a problem related to a small capacity pumps efficiency. Input exergy flow for small capacity pumps up to $3,5 \mathrm{~m}^{3} / \mathrm{h}$ (they are used as circulation pumps in small systems) differs from the "pure" exergy capacity transmitted to stream by approx 2,5 times.

For simplicity, it was assumed that a pump transfers to the stream only work form energy. Though small pumps share in overall system energy flow balances, they usually (eg circulation pump case) have long operation hours and in the long run generate tangible energy demands. Small pumps efficiency problem declines when flow rate starts to rise. Estimating actual exergy requirements for flow transportation due to the pumps inefficient work, an additional parameter $\varepsilon_{p}$ should be introduced in Eq 6:

$$
\frac{\stackrel{E_{p}}{\bullet}}{\dot{Q_{t h}}}=\frac{l \cdot \lambda}{d \cdot 2 \varepsilon} \frac{c^{2}}{c_{p} \cdot\left(t_{\text {in }}-t_{\text {out }}\right) \cdot \varepsilon_{p}}
$$

$\varepsilon_{p}$ - overall pump efficiency, which defines pump useful work (power) input and granted flow mass impulse output ratio. As it has been mentioned before, $\varepsilon_{p}$ is a function of mass flow rate. Assuming average fluids (hot water) parameters in building heating systems, $\varepsilon_{p}$ and energy flow relation can be expressed as it is presented in Fig 1.

It is important to stress that Fig 1 illustrates an actual relation based on the present technology level and it will develop according to the equipment efficiency grow. 


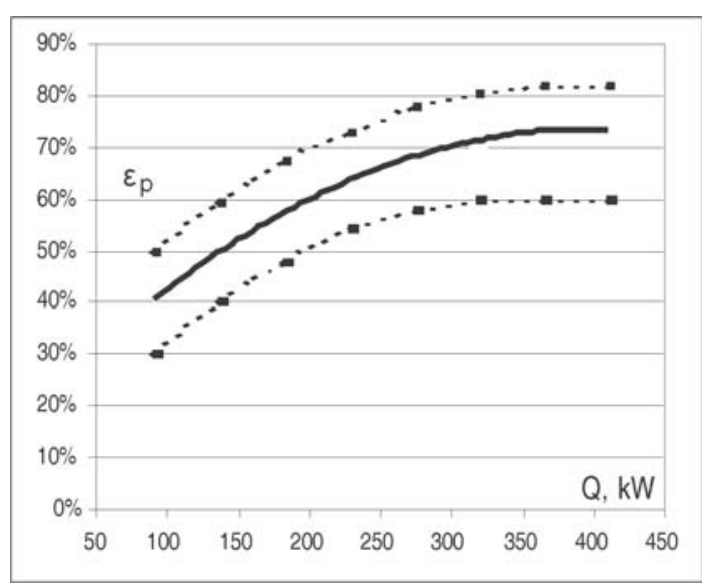

Fig 1. Pumps overall efficiency and heat flow ratio

The dotted lines present possible pumps efficiency variation intervals that usually do not exceed $10 \%$ limit.

The energy demand is identified through an assessment of direct building engineering systems energy flows and their parameters. When using an integral long-term exergy evaluation concept for building engineering systems, it is highly important to pay an adequate attention to the methods of energy generation technology, transportation and energy dispersion in the environment of the final user. Preliminary analysis showed that, according to present technological levels, the greatest influence on the integral exergy supply chain is from the segment of energy generation.

This paper deals with internal building energy supply problem, when estimating minimal energy quantity and quality requirements that should be supplied to the building boundaries. This paper does not follow sequential energy generation, distribution and consumption line, in this case their own buildings exergy demands are investigated. Overall primary energy (PE) (chemical energy contained in fuel) demand for BSS is presented only for the matter of comparison.

BSS systems exergy requirements for its decommissioning are investigated only on the basis of other authors' presented findings.

\section{Research objects}

When performing this work, four office-building models were created. The model generation was based on the standards that regulate office building designing [7]. Number of building floors varied from 2 to 8 , size 1,200 to $19,500 \mathrm{~m}^{2}$. When calculating the buildings energy demands, Vilnius city climatic data were used.

For the buildings a collector-heating system was designed. It is assumed that a mechanical constant flow ventilation system with $75 \%$ heat recovery was necessary. The system operates at 12/7. The exergy demand for the lighting system analysis was selected from the empirical data [8].
The amount of energy that is consumed by the building engineering systems during a standard year was estimated by using an integral heat demand duration chart [9]. The heating season duration is 199 days. Three days average outdoor temperature (equals $+8 \mathrm{rC}$ ) defines the beginning and ending date of the heating season. The calculation results were converted into the comparable exergy expenditures for $1 \mathrm{~m}^{2}$ of building area.

\section{Results}

Exergy demands for building service systems production are estimated according to the amount of materials contained in these systems. Having in mind that some data about the exergy use are contradictory or not available, exergy demands were calculated only for the main systems elements.

This work does not deal with exergy demand analysis for the lighting system production period. It is assumed that the energy amount consumed during the system production period is negligible.

Exergy demand for material production is presented in Table 1.

Table 1. Exergy demand for system production

\begin{tabular}{l|c|c|c|c}
\hline \multirow{2}{*}{ System name } & \multicolumn{4}{|c}{ Exergy demands for production, $\mathrm{MJ} / \mathrm{m}^{2}$} \\
\cline { 2 - 5 } & $\mathrm{I}$ & $\mathrm{II}$ & $\mathrm{III}$ & $\mathrm{IV}$ \\
\hline Heating & 82 & 51 & 44 & 40 \\
\hline Ventilation & 222 & 141 & 136 & 152 \\
\hline
\end{tabular}

Numbers I, II, II and IV in Table 1 represent different buildings analysed varying by space area and floor number.

When analysing building construction (structural) part, exergy demand indicators were used according to the data presented in $[10,11]$.

Preventive and corrective maintenance was performed during the building service period. During the building's lifetime some parts were repaired and replaced. Exergy demands for these recurring needs are assumed to be equal to the initial exergy consumption for systems production.

Exergy demands analysis for the system O\&M period was performed in two ways. Firstly, it was estimated what amount of PE is needed to satisfy BSS demands with a respect to the consistent energy supply chain. Secondly, individual BSS exergy demands at the building boundary were calculated.

Power consumption for office lighting during a year ranges from 32 to $54 \mathrm{kWh} / \mathrm{m}^{2}$ [8]. Taking into consideration the fact that in this source presented buildings and buildings analysed in this work were placed in different climatic zones, the maximum power consumption was chosen $-5 \mathrm{kWh} / \mathrm{ft}^{2}$. This is equal to $194 \mathrm{MJ}$ of power to $1 \mathrm{~m}^{2}$ of the building area. Exergy consumption ensuring a sufficient exergy flow to the final consumer during one normal year is presented in Table 2. 
Table 2. One-year exergy consumption in building's microclimatic systems

\begin{tabular}{|c|c|c|c|c|c|}
\hline & Unit & I & II & III & IV \\
\hline \multicolumn{6}{|c|}{ Exergy consumption including all energy supply chains } \\
\hline Lighting & \multirow{3}{*}{$\underset{\stackrel{N}{\Xi}}{\stackrel{N^{\prime}}{\Sigma}}$} & 380,2 & 380,2 & 380,2 & 380,2 \\
\hline Heating & & 180,4 & 111,3 & 93,0 & 84,8 \\
\hline Ventilation & & 147,6 & 160,6 & 133,4 & 131,2 \\
\hline \multicolumn{6}{|c|}{ Exergy consumption within building boundaries } \\
\hline Lighting & \multirow{3}{*}{ 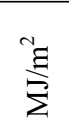 } & 194,0 & 194,0 & 194,0 & 194,0 \\
\hline Heating & & 80,2 & 49,4 & 41,3 & 37,7 \\
\hline Ventilation & & 66,7 & 72,5 & 60,2 & 59,2 \\
\hline
\end{tabular}

The comparison between building service systems exergy requirements for a life cycle is displayed in Fig 2.

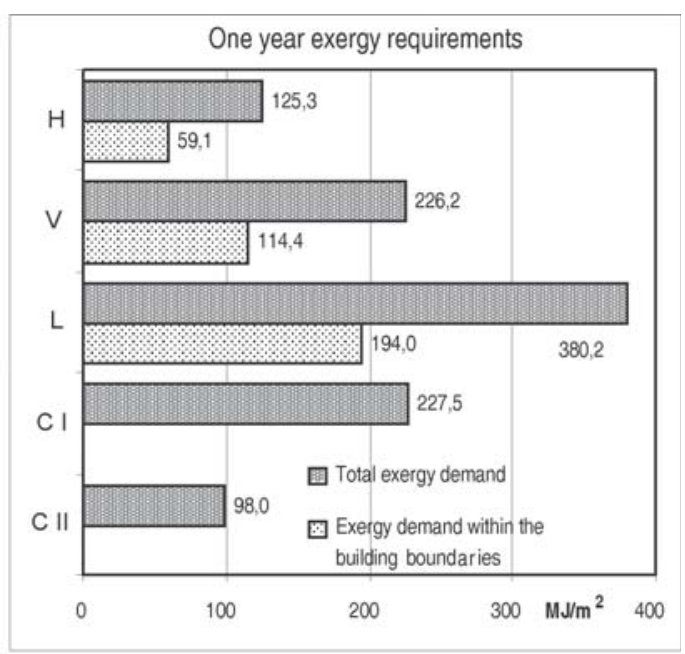

Fig 2. One-year exergy demand: $\mathrm{H}$ - heating, $\mathrm{V}$ - ventilation, L - lighting, C - construction

In Fig 2 presented BSS exergy demand within the buildings boundaries also includes exergy requirements for production maintenance and decommissioning needs. The total exergy demand for building construction consists of three parts: production (initial exergy), maintenance (replacement) and decommissioning. According to [11], exergy consumption for a building and the building material production takes $4,79 \mathrm{GJ} / \mathrm{m}^{2}$. In other sources [10] this value is $5,67 \mathrm{GJ} / \mathrm{m}^{2}$ In this case the prevailing construction material is concrete. The presented values are calculated according to the building lifetime of 50 and 75 years. Significant variation in the amount of defined maintenance exergy consumptions expresses different evaluations of the maintenance performance.

The high value of exergy demand presented in the [11] could be explained by the original office-building maintenance properties. For these types of buildings the indoor environment changes more frequently (eg furniture, finish) than their actual lifetime. The building functions and features are the main reasons outlining these frequent processes. The exergy demand for a building demolition takes up to 1 to $3 \%$ [11] of building construction exergy. Orientation values named by the au- thors $[10,11]$ are 136 and $350 \mathrm{MJ} / \mathrm{m}^{2}$. The mismatching of these values is reasoned by a different approach to the decommissioning process when the quantitative and qualitative criteria have been estimated differently.

The building microclimate conditioning systems have a different exergy demand conjunction. Besides, the exergy demand for a system production, maintenance and decommissioning, emerges the total system's operation exergy demand. It rates energy demands needed to run the systems and maintain required comfort conditions in the building.

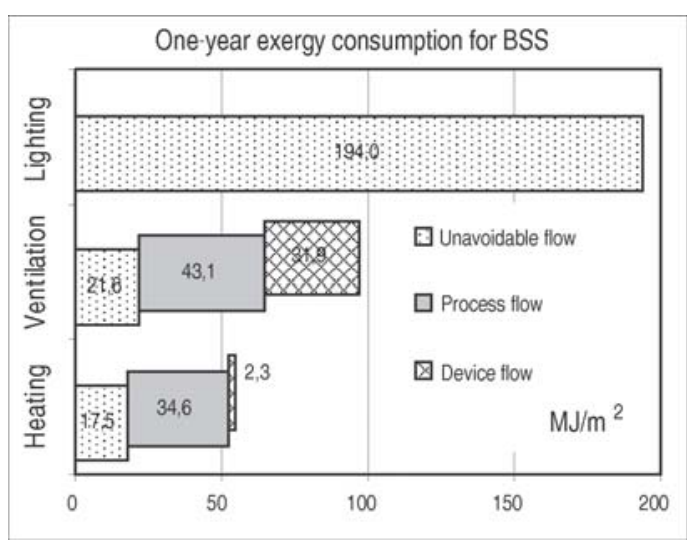

Fig 3. Exergy consumption in BSS within buildings boundaries

Fig 3 indicates three different exergy demand patterns for BSS (of buildings analysed): unavoidable, processes and devices. Mono systems exergy demand is not marked, this component being included in processes and devices exergy demand calculations. In order to determine mono systems exergy requirements, a more detailed analysis should be performed.

As it is presented in Fig 3, the largest unavoidable exergy demand belongs to the building lighting system. This statement is based on the previous assumption concerning the electricity use for the unavoidable lighting system exergy demands. Process exergy demands in heating and ventilation systems have notable share and indicates that along these systems a number of energy transformation (exergy losses generation) processes takes place. Exergy demands supplied to the devices vary but the highest level is in ventilation systems. Hidronic systems, in our case heating, show rather low exergy demands for flow transport. As presented in Fig 3, BSS exergy demand has its own structure. The biggest part (66\%) of required to supply exergy has to be electricity (useful work) as the rest in the heat form (data from three BSS analysed). In general, the tendency can mark out that modern buildings energy demands change its structure, more complex processes take place in BSS increasing the electricity demand.

Exergy demands for building microclimate conditioning system demolition are rather small. In this work it is assumed that they take about $2 / 3$ of the system production exergy demand. 


\section{Conclusions}

In order to ensure a sustainable use of resources, it is necessary to pay attention not only to the energy consumption during the system service period but to evaluate the total life-cycle energy demands.

One of the ways that enables a qualitative evaluation of the consumed energy is performing a system life cycle thermo-dynamical analysis. The qualitative criterion of energy processes estimated during the employment of the exergetical research method allows a new assessment level for the effectiveness of energy transformation process.

A broader life-cycle thermo-dynamical analysis application to the system design level provides an opportunity to minimise exergy demands and ensures further integration of the building microclimate conditioning systems.

Buildings as separate technical system exergy demand minimisation in elements production period is complicated. Manufacturing involves many parties when the collaboration between them is weak. Probable energy consumption efficiency growth in this area can be related only to a full-scale technological level increase. Building maintenance period possibilities to increase building energy consumption efficiency are more favourable. One of the ways that has a certain potential is BSS integration. It is linked to the minimisation of technological exergy flows because the unavoidable BSS exergy flows cannot be changed.

Performing a more detailed analysis, it is necessary to evaluate the character of changing outdoor climatic conditions. This problem has not been included in this paper.

\section{References}

1. Čiuprinskas, K.; Martinaitis, V. Particularities of determining primary energy needs for building materials. Statyba (now known as Journal of Civil Engineering and Management), No 3(11), 1997, p. 35-43 (in Lithuanian).

2. Buchanan, A. H.; Honey, B. G. Energy and carbon dioxide implications of building construction. Journal of Energy and Buildings, Vol 20, No 3, 1994, p. 205-217.

3. Martinaitis, V. Thermodynamical analysis model of building life cycle. Summary of the research report presented for Habilitation. Vilnius: Technika, 2000. 64 p.

4. Martinaitis, V. Thermodynamical analysis model of building life cycle. Monograph. Vilnius: Technika, 2001. 172 p. (in Lithuanian).

5. Skagnavi, A. H. Construction and calculation of building's heating systems: water and air heating (Конструирование и расчет систем водяного и воздушного отопления зданий). Moscow: Strojizdat, 1983 (in Russian).

6. Falhen, P.; Voll, H.; Naumov, J. Efficiency of pump operation in hydronic heating and cooling systems. In: 6th Intern Conf Proceedings on Energy for Buildings. Vilnius: Technika, 2004. 547 p.

7. SNiP 2.09.04-87* Office and residential buildings. Building Code (СНиП 2.09.04-87 Административные и бытовые здания. Строительные нормы и правила). Moscow: Gosstroj SSSR, 1989 (in Russian).

8. Weigand, D. E.; Benyja, J.; Heschong, L. et al. Advanced lighting guidelines. New buildings institute, Inc. 2003. $445 \mathrm{p}$.

9. Lithuanian building standards 156-94. Building climatology, Vilnius, 1995 (in Lithuanian).

10. Scheuer, C.; Koelein, G.; Reppe, A. P. Life cycle energy and environmental performance of a new university building: modelling challenges and design implications. Journal of Energy and Buildings, Vol 35, No 10, p. 1049-1064.

11. Cole, R. J.; Kernan, P. C. Life-cycle energy use in office buildings. Journal of Building and Environment, No 31(4), 1996, p. 307-317.

\section{PASTATO INŽINERINIŲ SISTEMŲ PIRMINĖS ENERGIJOS POREIKIŲ IVERTINIMAS}

\section{Biekša, V. Martinaitis, A. A. Šakmanas}

Santrauka

Šiame darbe analizuojamas pastato inžinerinėms sistemoms reikalingi pirminės energijos poreikiai. Tyrime nagrinėjamos dideliu energijos imlumu išsiskiriančios visuomeninių pastatų inžinerinès sistemos. Tai šildymas, vedinimas ir apšvietimas. Pirminès energijos poreikių analizė suskirstyta į sistemų îrengimą, naudojimą bei išardymą, t. y. etapus, besiskiriančius pagal pirminès energijos poreikio mastą ir vartojimo intensyvumą. Pagrindinis dėmesys darbe skiriamas sistemų naudojimo laikotarpiu suvartojamos pirminès energijos sąnaudoms identifikuoti. Pastato inžinerinių sistemų pirminès energijos poreikiai yra įvertinti kaip iki pastato ribos būtinas patiekti pirminès energijos kiekis. Tirti 4 pastatai, kuriems buvo pritaikytos Vilniaus miesto klimato sąlygos.

Raktažodžiai: pastatų inžinerinès sistemos, pirminès energijos sąnaudos, procesų integracija.

Darius BIEKŠA. MSc, PhD student in Dept of Heating and Ventilation, Vilnius Gediminas Technical University, Vilnius, Lithuania. Research interests: building engineering systems, exergy consumption, process integration.

Vytautas MARTINAITIS. Professor, Head of Heating and Ventilation Dept of Vilnius Gediminas Technical University, Doctor Habil of Energy and Thermal Engineering Sciences. The area of his scientific interests is energy use and supply systems for indoor climate of sustainable housing: thermodynamic, exergy and life cycle analysis; energy planning and demand side management; energy audit and renovation. Author and co-author of more than 80 scientific and technical articles.

Aloyzas Algimantas ŠAKMANAS. Assoc Prof of Heating and Ventilation Dept, Vilnius Gediminas Technical University, Vilnius, Lithuania. Research interests: building materials, building engineering systems, heat transfer problems. 